\title{
Adsorption by Granular Activated Carbon and Nano Zerovalent Iron from Wastewater: A Study on Removal of Selenomethionine and Selenocysteine
}

\author{
Stanley Onyinye Okonji ${ }^{1}\left(\right.$, Linlong $\mathrm{Yu}^{2}{ }^{2}$, John Albino Dominic ${ }^{2}$, David Pernitsky ${ }^{3}$ and Gopal Achari ${ }^{2, *(D)}$ \\ 1 Department of Mechanical \& Manufacturing Engineering, University of Calgary, ICT 402, \\ 2500 University Drive NW, Calgary, AB T2N 1N4, Canada; stanley.okonji@ucalgary.ca \\ 2 Department of Civil Engineering, University of Calgary, ENF 262, 2500 University Drive NW, Calgary, \\ AB T2N 1N4, Canada; linyu@ucalgary.ca (L.Y.); johnalbino.dominic@ucalgary.ca (J.A.D.) \\ 3 Stantec, 200-325 25 Street SE, Calgary, AB T2A 7H8, Canada; David.Pernitsky@stantec.com \\ * Correspondence: gachari@ucalgary.ca
}

check for updates

Citation: Okonji, S.O.; Yu, L.;

Dominic, J.A.; Pernitsky, D.; Achari,

G. Adsorption by Granular Activated Carbon and Nano Zerovalent Iron from Wastewater: A Study on

Removal of Selenomethionine and Selenocysteine. Water 2021, 13, 23 https://dx.doi.org/10.3390/w13010023

Received: 26 November 2020 Accepted: 22 December 2020 Published: 25 December 2020

Publisher's Note: MDPI stays neutral with regard to jurisdictional claims in published maps and institutional affiliations.

Copyright: () 2020 by the authors. Licensee MDPI, Basel, Switzerland. This article is an open access article distributed under the terms and conditions of the Creative Commons Attribution (CC BY) license (https: / / creativecommons.org/ licenses/by/4.0/).

\begin{abstract}
Selenomethionine (SeMet) and selenocysteine (SeCys) are the most common forms of organic selenium, which is often found in the effluent of industrial wastewater. These organic selenium compounds are toxic, bioavailable and most likely to bioaccumulate in aquatic organisms. This study investigated the use of two adsorbent candidates (granular activated carbon (GAC) and nano zerovalent iron (nZVI)) as treatment technologies for SeMet and SeCys removal. Batch experiments were performed and inductively coupled plasma optical emission spectrometer (ICP-OES) was used for sample analysis. Experimental data showed GAC demonstrated a higher affinity towards the removal of SeMet and SeCys compared to nZVI. The removal efficiency of SeCys and SeMet by GAC was $96.1 \%$ and $86.7 \%$, respectively. NZVI adsorption capacity for SeCys was $39.4 \%$ and SeMet $<1.1 \%$. Irrespective of the adsorbent, SeMet is more refractory to be adsorbed compared to SeCys. Kinetics data of GAC and nZVI agreed well with the pseudo-second-order model $\left(R^{2}>0.990\right)$. The experimental data of SeCys was characterized by Langmuir model, indicating monolayer adsorption. The adsorption capacity of nZVI for SeCys increased significantly by about $35 \%$, with a decrease in $\mathrm{pH}$ from 9.0 to 4.0, indicating that SeCy removal by $\mathrm{nZVI}$ is $\mathrm{pH}$ dependent. While electrostatic attraction is considered the driving mechanism for nZVI adsorption, GAC uptake capacity is controlled by weak van der Waal forces. The adsorption of binary adsorbates (SeMet and SeCys) exhibited an inhibitory effect due to the competitive interaction between contaminant molecules.
\end{abstract}

Keywords: adsorption; nano zerovalent iron; granular activated carbon; organoselenium; water; wastewater; treatment

\section{Introduction}

Organoselenium simply refers to compounds that contain selenium (Se) in combination with other elements, such as carbon, oxygen, hydrogen, and nitrogen as part of their structure. The primary form of organic Se is selenoamino acids and selenoproteins [1]. SeMet and SeCys are the most common forms by which Se-amino acids exist in the environment and are uptaken by plants and aquatic organisms [2,3]. Naturally, SeMet and SeCys are organically bound in foods, such as nuts, yeast, eggs, liver, garlic [1,3]. In general, Se is a trace element essential for living organism physiological processes at a concentration range from $63-135 \mu \mathrm{g} / \mathrm{L}$ but exhibits toxicity outside this range of concentration [4].

In aqueous environments, organic selenium can be categorized as an emerging contaminant. It exists in the form of SeMet and SeCys in the effluent of industrial wastewaters [5], emanating from mostly mining, oil and gas refineries and coal-fired power plants. SeMet and SeCys are known to have higher bioavailability than inorganic selenium species as it is readily absorbed $[3,5]$. As a result, the ecotoxicological effect of organic Se (SeMet 
and SeCys) in aqueous environments is increased. One of the major concerns of organic selenium is the tendency to accumulate in aquatic organisms for an extended period of time, resulting in the contamination of fish and wildlife diets [6]. Public health is at risk if humans consume selenium-contaminated fish and wildlife [7]. The US EPA recently set environmental Se threshold regulations to be reliant on biotic tissue-based concentration rather than the traditional aqueous concentration limit [8]. This regulation is key to preventing organic Se propensity to bioaccumulate within the food-web. Therefore, it is essential to remove organic selenium contaminants from industrial wastewaters in order to decrease the bioaccumulation of selenium in aquatic life, the adverse impact on the ecosystem and the threat to public health. However, there are limited options available for the industries to meet this regulation.

To date, research on selenium remediation in aqueous media has largely focused on inorganic selenium removal. Various treatment technologies have been explored to remove Se from industrial wastewater. These are broadly classified into physical, chemical and biological treatment processes $[9,10]$. The following studies investigated these removal technologies: elemental selenium $\left(\mathrm{Se}^{0}\right)$ precipitation [11,12], iron coprecipitation methods [13], ion-exchange [14], adsorption using mineral adsorbents [15-21], coagulation [22], electrocoagulation [14] and photocatalytic reduction [23,24]. The biological treatment method is the most commonly used remediation technology for inorganic Se removal [10]. The process relies on the use of microbial mediation for selenium species removal [25-28]. However, the presence of SeMet has been reported in the effluents of an industrial biological treatment system [5]. It stands to reason that biological treatment techniques are among the primary sources of organic Se pollution in wastewaters. The transformation of inorganic selenium species to the organic form is mainly due to the microbial activities $[5,29]$. As a result, the existence of organic Se (SeMet and SeCys) in wastewaters remains an environmental contaminant of concern and the remediation techniques have rarely been researched.

So far, very few studies had investigated organic selenium removal from wastewaters. Alain (1997) investigated the removal of selenocyanate $\left(\mathrm{SeCN}^{-}\right)$from sour crude oil produced wastewater by copper (II) salt precipitation [30]. Meng 2002 [31] studied the removal of selenocyanate $\left(\mathrm{SeCN}^{-}\right)$from wastewater using $\mathrm{Fe}(0)$ filings through the formation of elemental selenium $\left(\mathrm{Se}^{0}\right)$. Sanna (2003) studied seleno-DL-methionine separation from inorganic selenium solution using magnesium-loaded activated charcoal [32]. However, besides our earlier study on SeMet removal [33], no previous research has investigated the removal of SeMet and SeCys from wastewater.

This study was conducted to determine the removal of SeMet and SeCys from wastewaters by (granular activated carbon (GAC) and nano zerovalent iron (nZVI)) adsorption, which have shown promise in treating inorganic selenium [34-36]. In this research, adsorption kinetics and isotherms of the two adsorbents were investigated. The effects of $\mathrm{pH}$, initial adsorbate concentrations on adsorption capacities and the influence of binary adsorption were evaluated. SeMet and SeCys were selected as probe contaminants due to its toxicity and bioavailability in the wastewater, while the choice of adsorbents was driven by inexpensive cost and their being environmental benign $[37,38]$. This is the first study investigating the mechanism of GAC and nZVI to remove organic selenium from industrial wastewater. The knowledge gain in this study will benefit the development of efficient treatment processes for SeMet and SeCys using GAC and nZVI.

\section{Materials and Methods}

\subsection{Chemicals}

All chemicals employed in this study were used as received. Selenomethionine (>98\%) and selenocysteine (>98\%) were purchased from TCI America. Hydrochloric acid $(\mathrm{HCl})$ (>98\%), sodium hydroxide $(\mathrm{NaOH})(>98 \%)$, nano zerovalent iron (nZVI 60-80 nm >99\%) were procured from Sigma-Aldrich Chemical Company. Granular activated carbon was acquired from Evoqua (Pittsburgh). 


\subsection{Characterization of Adsorbents}

The morphological properties of the adsorbents were obtained on a scanning electron microscope (SEM, ThermoFisher, Quanta FEG 250), as shown in Figure 1. BET surface area and total pore volume were obtained by $\mathrm{N}_{2}$ adsorption at $77 \mathrm{~K}$ on a PMI Automated Brunauer-Emmett-Teller (BET), Quantachrome ChemBet (3000 CB-SCL).
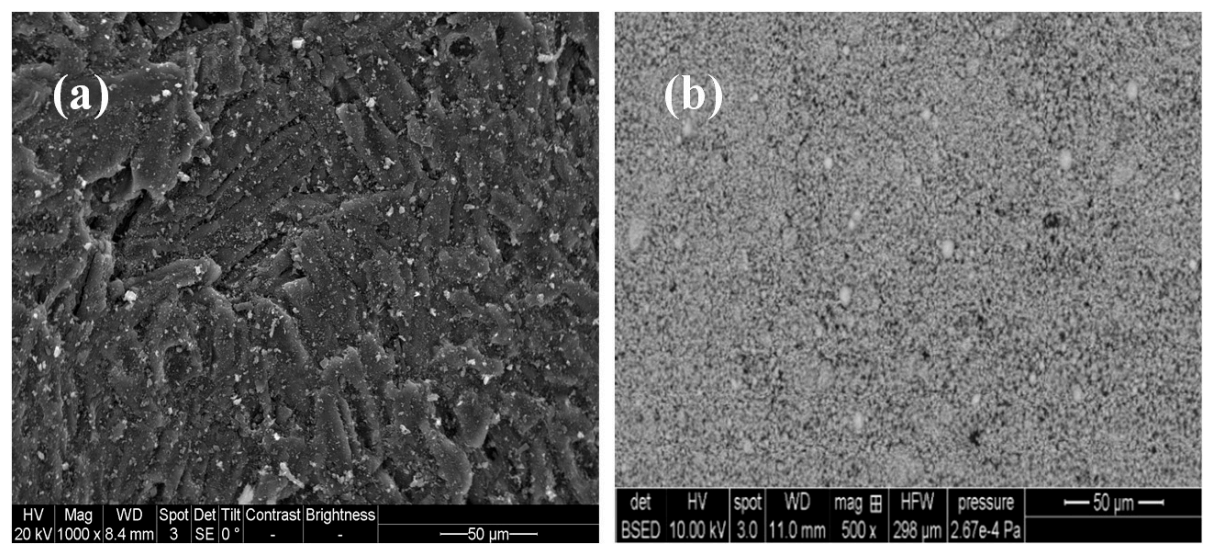

Figure 1. SEM images of granular activated carbon (a) and nZVI (b).

\subsection{Batch Adsorption Studies}

Selenocysteine $\left(\mathrm{C}_{3} \mathrm{H}_{7} \mathrm{NO}_{2} \mathrm{Se}\right)$ and Selenomethionine $\left(\mathrm{C}_{5} \mathrm{H}_{11} \mathrm{NO}_{2} \mathrm{Se}\right)$ stock solution were prepared separately by dissolving $0.5 \mathrm{~g}$ of both compounds in $100 \mathrm{~mL}$ of deionized water. The stock solution was diluted appropriately to obtain working solutions of various concentrations, as needed. The concentration of SeMet and SeCys in working solutions, used for adsorbent dose studies, $\mathrm{pH}$ studies, initial adsorbate concentrations and adsorption kinetics, was $5 \mathrm{mg} / \mathrm{L}$. Table 1 illustrates the summary of experimental conditions with respect to the adsorbents and their respective concentrations used for evaluating adsorbent dose studies. The effect of $\mathrm{pH}$ on the adsorption of SeMet and SeCys was investigated by conducting experiments with different $\mathrm{pH}$ conditions (4.0, 7.0 and 9.0). Batch experiments were performed using straight-wall glass jars of $150 \mathrm{~mL}$ volume. A magnetic stirrer (VWR 200 model) was used to stir the solutions; the mixtures was agitated at a constant shaking speed of $180 \mathrm{rpm}$ in a temperature-controlled orbital shaker. All experiments were conducted at ambient temperature. The initial $\mathrm{pH}$ of the solution was adjusted by adding $\mathrm{HCl}$ or $\mathrm{NaOH}(1 \mathrm{M})$. At different time intervals, aliquots of $10 \mathrm{~mL}$ samples were periodically taken and immediately filtered using $0.22 \mu \mathrm{m}$ PTFE syringe filter. The collected samples were acidified using $50 \%$ nitric acid for a resulting strength of $2 \%$ and stored at $4{ }^{\circ} \mathrm{C}$ before analysis. For statistical reliability, all the experiments were conducted in duplicate, the samples were analyzed in triplicate and standard deviation was used for error analysis.

Table 1. Summary of experimental conditions for adsorbent dose.

\begin{tabular}{lcccc}
\hline & \multicolumn{2}{c}{ SeCys } & \multicolumn{2}{c}{ SeMet } \\
\hline Adsorbent Type & GAC & nZVI & GAC & nZVI \\
\hline \multirow{5}{*}{ Dosage (g/L) } & 1 & - & 1 & - \\
& 2 & 2 & 2 & - \\
& 3 & - & 3 & - \\
& 5 & - & 5 & 7 \\
\hline
\end{tabular}




\subsection{Analysis and Equipment}

The total Se concentration in the samples was analyzed using an inductively coupled plasma optical emission spectrometer (ICP-OES) (Thermo Scientific icap 7000 series). The limit of detection and quantitation for selenium was estimated as 0.005 and $0.01 \mathrm{mg} / \mathrm{L}$, respectively. The $\mathrm{pH}$ fluctuations in the system with time were measured with a $\mathrm{pH}$ digital instrument symphony B20PI VWR. The analysis in this study did not distinguish between the species of organic selenium. The total selenium concentration was measured and analyzed.

\subsection{Adsorption Kinetics}

Adsorption kinetics were examined for an SeMet and SeCys initial concentration of $5 \mathrm{mg} / \mathrm{L}$ using nZVI and GAC adsorbent. An adsorbent loading rate of $7 \mathrm{~g} / \mathrm{L}$ was used and the adsorption capacity $q_{e}(m g / g)$ was calculated using the expression (Equation (1)):

$$
q_{e}=\frac{C_{o}-C_{e}}{M} V
$$

where $C_{o}$ and $C_{e}$ represent initial and equilibrium concentrations (mg/L), respectively; $M$ is the mass of the adsorbent (g); $V$ is the volume of the solution (L). A pseudo-secondorder kinetic model was applied to the kinetic data; the mathematical expression is shown in Equation (2):

$$
\frac{t}{q_{t}}=\frac{1}{k_{2} q_{e}^{2}}+\frac{t}{q_{e}}
$$

where $q_{e}$ and $q_{t}(\mathrm{mg} / \mathrm{g})$ represent the amount of adsorbate adsorbed at equilibrium and time $(\mathrm{t})$, respectively; $k_{2}$ is pseudo-second-order kinetic rate constant $\left(\mathrm{g} \cdot \mathrm{mg}^{-1} \mathrm{~min}^{-1}\right)$ and adsorption time ( $\mathrm{min})$. The initial adsorption rate $h$ of the system is equal to $k_{2} q_{e}^{2}\left(\mathrm{mg}^{-g^{-1}} \mathrm{~min}^{-1}\right)$. Equation (3) shows the pseudo-first-order kinetic model:

$$
q_{t}=q_{e}\left(1-e^{-k t}\right)
$$

where $k\left(\mathrm{~min}^{-1}\right)$ is the rate constant; other parameters in the expression have been defined above.

\subsection{Adsorption Isotherm Studies}

Adsorption isotherm studies were conducted with various initial concentrations (5 to $47.2 \mathrm{mg} / \mathrm{L}$ ) for SeMet and SeCys. Freundlich and Langmuir isotherm models were used to evaluate the adsorption isotherm. The Freundlich model describes the relationship between the equilibrium concentration and the adsorption capacity. Equation (4) describes the nonlinear Freundlich adsorption isotherm model [39]:

$$
\frac{\left(C_{o}-C_{e}\right)}{M} V=K_{f} C_{e}^{\frac{1}{n}}
$$

where $C_{e}$ is the equilibrium concentration $(\mathrm{mg} / \mathrm{L}), C_{o}$ is the initial concentration $(\mathrm{mg} / \mathrm{L})$, $M$ is the mass of adsorbent $(\mathrm{g}), V$ is the volume of the solution $(\mathrm{L}), K_{f}$ and $n$ are Freundlich constants. The left-hand side of the Equation can be determined from experimental data, and it denotes the mass of adsorbate adsorbed per unit mass of adsorbent. The mathematical expression of Langmuir isotherm model [40] is given in Equation (5):

$$
q_{e}=q_{m} K_{c} \frac{C_{e}}{1+K_{c} C_{e}}
$$

where $q_{e}$ is the adsorption capacity at equilibrium $(\mathrm{mgSe} / \mathrm{g}), q_{m}(\mathrm{mgSe} / \mathrm{g})$ is the maximum adsorption capacity, $K_{c}(\mathrm{~L} / \mathrm{mg})$ defined the equilibrium adsorption constants and $C_{e}$ is the equilibrium concentration $(\mathrm{mg} / \mathrm{L})$. The Langmuir isotherm is based on the assumption 
that adsorption can occur at a finite number of specific localized sites (monolayer) [40]. Equation (6) can be used to evaluate the Langmuir model further [41].

$$
R_{L}=\frac{1}{1+K_{c} C_{o}}
$$

The value of $R_{L}$ defines the adsorption process as irreversible when $\left(R_{L}=0\right)$, favorable $\left(1>R_{L}>0\right)$, unfavorable $\left(R_{L}>1\right)$ and linear $\left(R_{L}=1\right)$.

\subsection{Parameter Study}

The impact of various parameters, including adsorbent dose, $\mathrm{pH}$ and initial adsorbate concentration on organic selenium adsorption were evaluated. The experimental conditions were described in Section 2.3 and are summarized in Table 1 (adsorbent dose). The adsorbent amount of $7 \mathrm{~g} / \mathrm{L}$ was chosen for all experiments based on the optimum dose determined in the dosage studies. For the binary adsorption experiment, a solution containing a mixture of SeMet and SeCys was used to study the effect of organic selenium coexistence. The initial concentration of the organoselenium was $5 \mathrm{mg} / \mathrm{L}$ each.

\section{Results and Discussion}

\subsection{Adsorption of Organic Selenium by nZVI and GAC}

The batch experiments result for the adsorption of organic selenium species (SeMet and SeCys) using $7 \mathrm{~g} / \mathrm{L}$ of nZVI and GAC are presented in Figure 2. As shown, the removal of SeCys and SeMet by GAC is more effective than nZVI. After $3 \mathrm{~h}$ of adsorption experiments, it was observed that $96 \%$ of SeCys and $86.76 \%$ of SeMet was removed from water by activated carbon, while $39.44 \%$ of SeCys and less than $1.05 \%$ of SeMet was transferred to nZVI from the aqueous phase. Physisorption and chemisorption are the two major mechanisms for activated carbon adsorption. The former is caused by relatively weak van der Waals forces formed between the adsorbates and activated carbon's surface. In contrast, the latter is driven by a chemical reaction between the adsorbate molecules and the adsorbent surface [42].

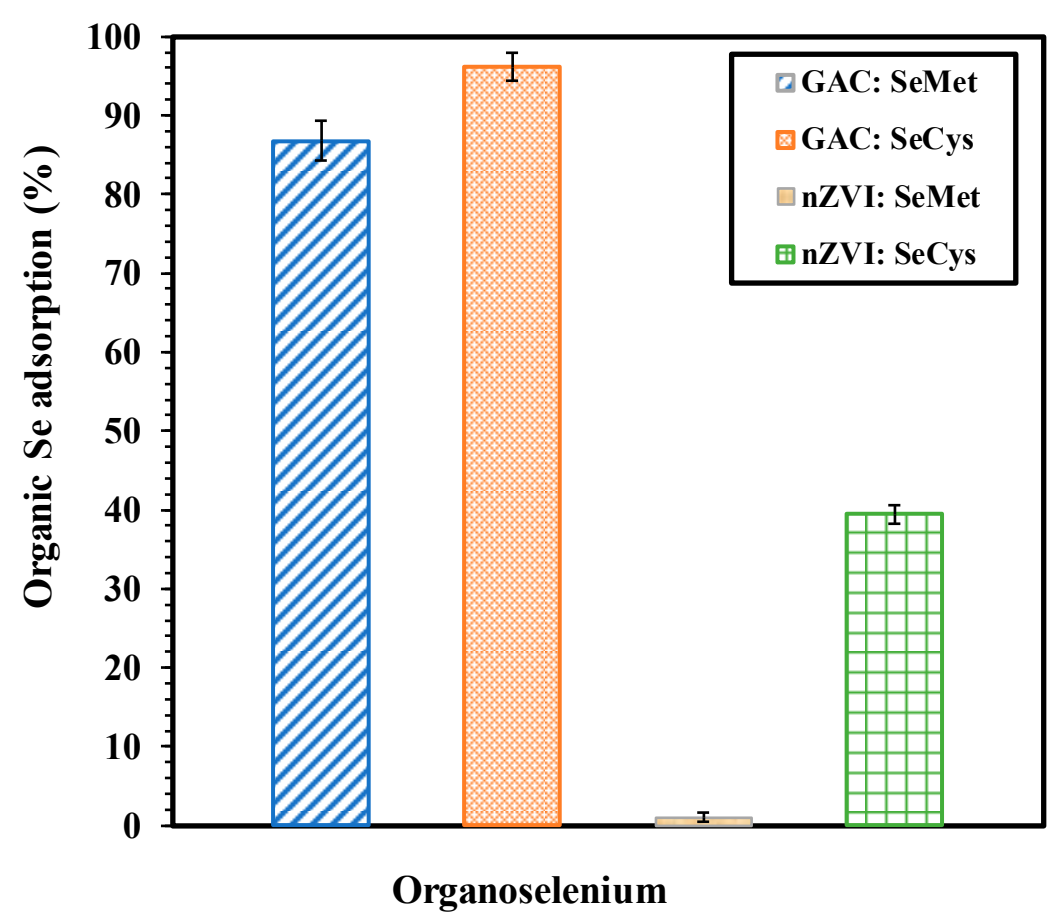

Figure 2. Comparison of organic selenium removal using $7 \mathrm{~g} / \mathrm{L}$ of GAC and nZVI, $\mathrm{pH} 7.0$, at $25^{\circ} \mathrm{C}$ for $3 \mathrm{~h}$ period. 
Conversely, the elemental iron (nZVI) removal mechanism for organic selenium (selenoyanate) is driven by a corrosion process, which removes the dense oxide layer and activates $\mathrm{Fe}(0)$ [31]. Meng [31] demonstrated that, when $\mathrm{Fe}(0)$ is mixed in water in the presence of dissolved oxygen (DO), $\mathrm{Fe}(0)$ is oxidized to ferrous ions. The oxidation process will give rise to ferric ions, which subsequently form loose ferric hydroxide in water. This phenomenon is referred to as the $\mathrm{Fe}(0)$ adsorption process [34], and it describes the nZVI removal mechanism of selenocyanates. In light of selenocyanate being an organic selenium compound and has similar characteristics, such as SeMet and SeCys, it is expected that a similar removal process may be applicable.

In comparison, GAC has better performance and can be attributed to the following reasons-(1) activated carbon possesses a microporous structure, which can lead to large active surface area $\left(\sim 1000 \mathrm{~m}^{2} / \mathrm{g}\right)$ [43], with BET pore volume $0.500\left(\mathrm{~cm}^{3} / \mathrm{g}\right)$, and average pore width $2.138(\mathrm{~nm})$. The second reason is that activated carbon-oxygen surface functional groups (e.g., carboxylic and phenolic groups) can react with SeCys and SeMet to form chemical bonds. SeMet and SeCys are known to contain amino and a carboxylic acid; the functional groups can create hydrogen-bonding with activated carbon surface oxygen $[44,45]$. Additionally, selenium has an electronegativity similar to sulfur and is capable of forming strong hydrogen bonds identical to sulfur and oxygen [46].

On the other hand, nZVI adsorption was weak; it can be ascribed to the limited number of active sites. The surface area is much smaller than GAC, usually less than $100 \mathrm{~m}^{2} / \mathrm{g}[47,48]$. The adsorption of SeCys and SeMet on metals has not been reported in the literature. However, the mechanism can possibly be understood through the published studies on the interaction between metals, cysteine and methionine. Selenocysteine is an analogue of cysteine with selenium in place of the sulfur, while selenomethionine is analogue of methionine with selenium in place of the sulfur. Therefore, it is expected that the contaminants would have similar behavior and interactions with iron. Generally, the first steps in the adsorption of cysteine or methionine on an iron surface involve the replacement of one or more water molecules adsorbed at the iron surfaces, followed by the formation of iron-cysteine/methionine complexes, as shown in Equations (7)-(9) [49]. It is reported that cysteine can bond to the metal surface through sulfur, two oxygen, and a nitrogen atom in a four-point "quadrangular footprint", while methionine adsorbs on the surface with two oxygen and a nitrogen atom in a "triangular footprint" [50]. The sulfur atom within the methionine molecule does not interact with the metal surface. The reaction between the sulfur atom and the metal substrate can form a strong bond [50,51], indicating that cysteine's adsorption is stronger than methionine. Similar to methionine, the selenium atom in SeMet is not expected to react with iron's surface, hence no strong bond; which explains the weak adsorption of SeMet on the surface of iron compared to selenocysteine.

$$
\begin{aligned}
& \text { Cystein } / \text { methione(sol) }+x \mathrm{H}_{2} \mathrm{O}(\text { ads }) \rightarrow \text { Cystein /methione (ads) }+x \mathrm{H}_{2} \mathrm{O}(\text { sol }) \\
& \mathrm{Fe} \rightarrow \mathrm{Fe}^{2+}+2 e \\
& \mathrm{Fe}^{2+}+\text { Cystein/methione (ads) } \rightarrow[\mathrm{Fe}-\text { Cystein } / \text { methione }]^{2+}(\text { ads })
\end{aligned}
$$

\subsection{Adsorbent Dosage}

Figure 3 presents the result of the adsorbent amount study on the uptake of SeMet and SeCys by GAC and nZVI with an initial concentration of $5 \mathrm{mg} / \mathrm{L}$ at $\mathrm{pH}$ 7.0. The removal percentage of organoselenium increased with an increase in the dose of GAC and nZVI. As shown in Figure 3, the effect of adsorbent dose on the organic selenium removal was more significant at the lower adsorbent loadings. Approximately $86.3 \%$ of SeCys and $57.1 \%$ of SeMet were removed by $1.0 \mathrm{~g} / \mathrm{L}$ of GAC in $3 \mathrm{~h}$. While $12.2 \%$ of SeCys was removed by nZVI within the same time frame. About $72.6 \%$ and $90 \%$ of SeMet was swiftly removed when the GAC dose was increased from 2 to $14 \mathrm{~g} / \mathrm{L}$, respectively. While $93 \%$ and $97.9 \%$ of SeCys were adsorbed from the solution with the same GAC loading. About $39.4 \%$ and 
$56.6 \%$ of SeCys were adsorbed by 7 and $14 \mathrm{~g} / \mathrm{L}$ of nZVI, respectively. The increase in the adsorption capacity of the adsorbent candidates (GAC and nZVI) is attributed to the availability of greater surface area that drives an increase in the number of active adsorption sites; therefore, resulting in a higher removal rate $[35,38]$. In contrast to nZVI adsorption, an optimum dose of $7 \mathrm{~g} / \mathrm{L}$ of GAC significantly adsorbed both contaminants.

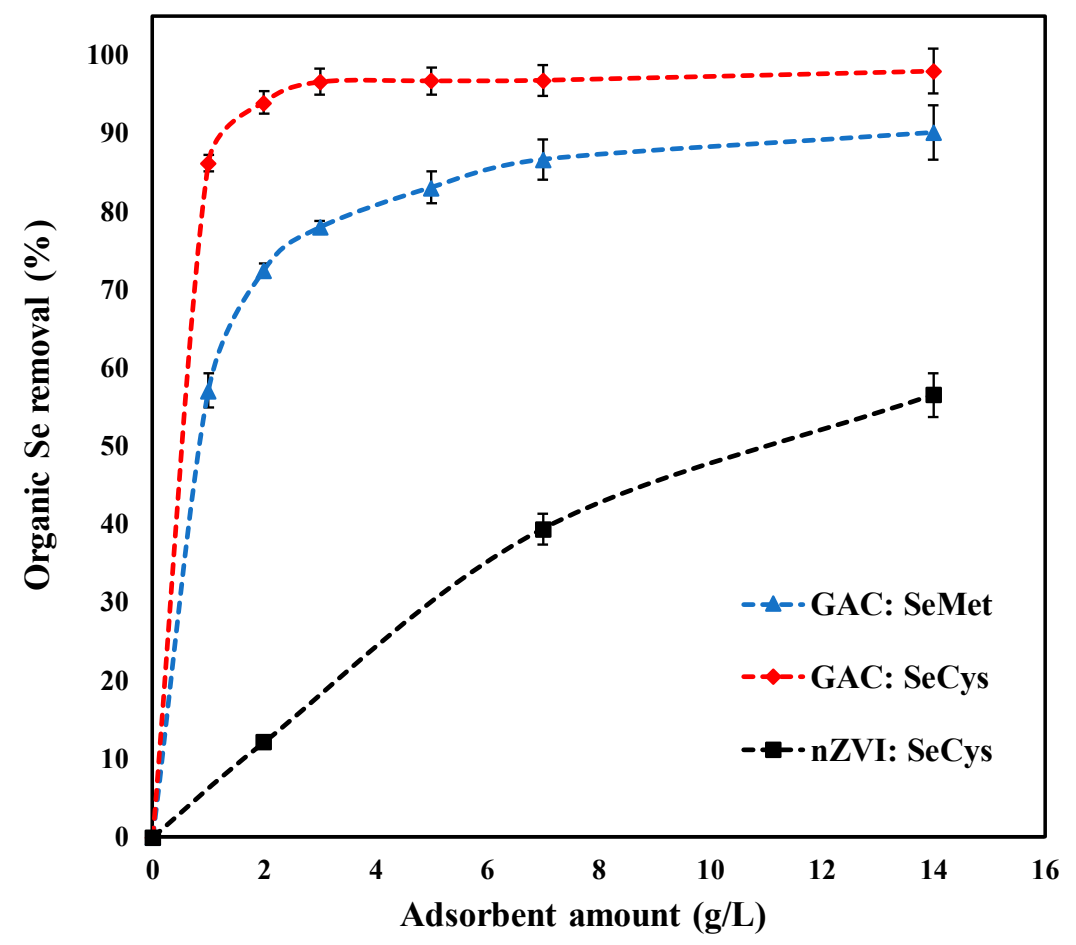

Figure 3. Effect of adsorbent dosage on organic selenium removal, by GAC and nZVI (initial concentration of $5 \mathrm{mg} / \mathrm{L}, \mathrm{pH} 7.0$, at $25^{\circ} \mathrm{C}$ ).

\subsection{Effect of $p H$}

Figure 4 depicts the results of experiments conducted to determine the $\mathrm{pH}$ influence on organic selenium adsorption by GAC and nZVI. The solutions $\mathrm{pH}$ level was measured at $\mathrm{pH}$ 4.0, 7.0 and 9.0 during mixing for $3 \mathrm{~h}$. As shown in Figure 4, the amount of SeMet and SeCys adsorbed onto GAC for acidic, neutral and alkaline $\mathrm{pH}$ was significant. The removal efficiency of SeCys by GAC occurred in the order of $94.7 \%, 96.1 \%$ and $96.8 \%$ for $\mathrm{pH} 4.0$, 7.0 and 9.0, respectively. The acidic condition was observed to be slightly less favorable for the adsorption of SeMet by GAC, corresponding to $80.3 \%$ removal. The removal of SeMet at pH 7.0 and 9.0 solution was $86.7 \%$ and $86.6 \%$, respectively. SeCys and SeMet are zwitterions, containing both amino groups and carboxyl groups. The isoelectric point (Ip) for SeMet and SeCys are 5.75 and 5.54, respectively [51,52]. Increasing the $\mathrm{pH}$ from 4.0 to 9.0 would change the net charge of SeCys and SeMet solution from positive to negative and also influence the surface charge of activated carbon, leading to different electrostatic interactions between SeCys and SeMet molecules and activated carbon. In this study, the investigated pHs insignificantly impacted the adsorption of the two organic selenium compounds by GAC, indicating that the adsorption of SeCys and SeMet by GAC was not dominated by electrostatic force. The adsorption of SeCys and SeMet could potentially occur as a result of the hydrogen bonding or the hydrophobic interaction that exists between the hydrophobic part of SeCys and SeMet molecules and the hydrophobic part of the adsorbent, which have been reported as mechanisms for the adsorption of amino acids on the surface of activated carbon [53]. 


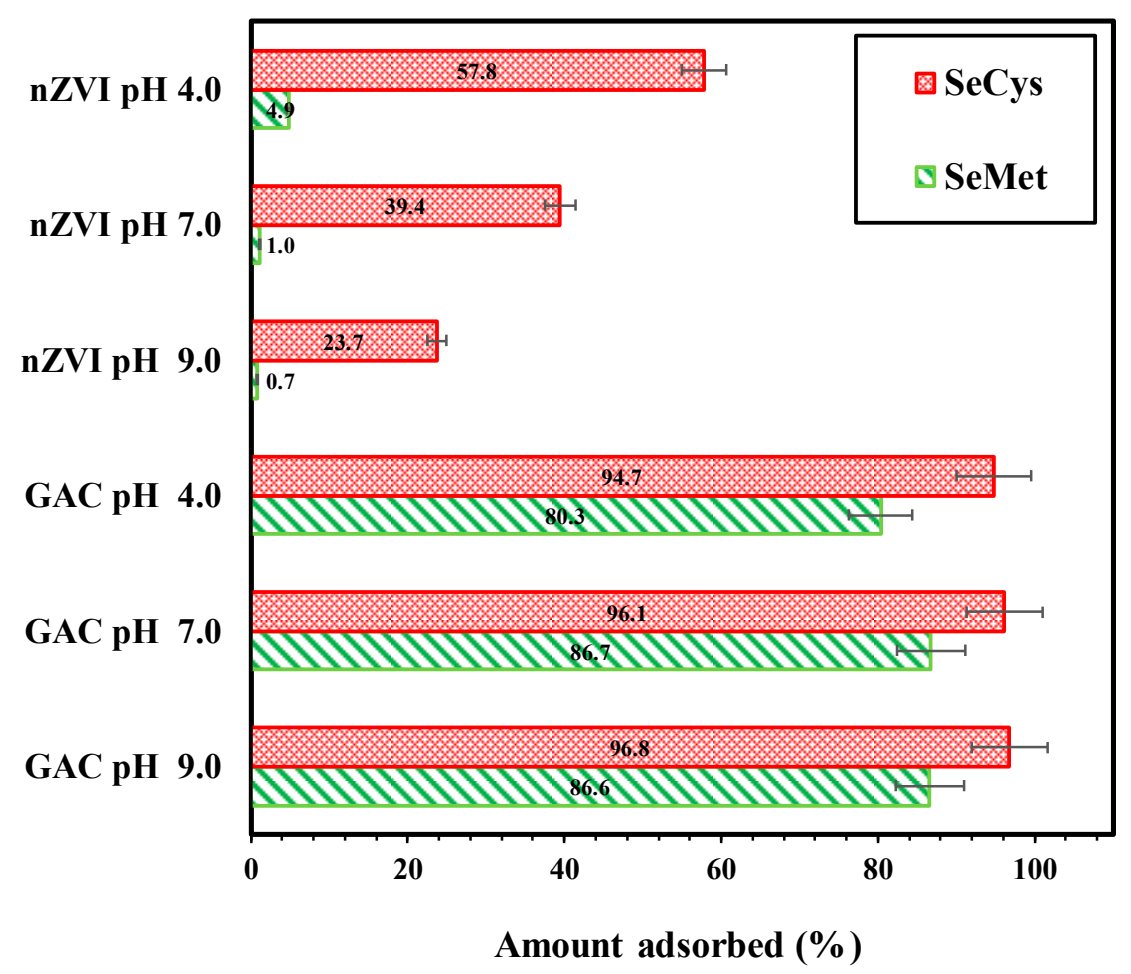

Figure 4. Effect of $\mathrm{pH}$ on SeMet and SeCys adsorption by GAC and nZVI, (initial concentration $5 \mathrm{mg} / \mathrm{L}, 7 \mathrm{~g} / \mathrm{L}, \mathrm{pH} 4.0,7.0$ and 9.0 , at $25^{\circ} \mathrm{C}$ ).

On the other hand, the removal of SeCys and SeMet by nZVI decreased remarkably with increasing $\mathrm{pH}$, as shown in Figure 4. The percentages of SeCys adsorbed on nZVI under different $\mathrm{pHs}$ are $57.8 \%$ for $\mathrm{pH}$ 4.0, 39.4\% for $\mathrm{pH} 7.0$ and $23.7 \%$ for $\mathrm{pH}$ 9.0. SeMet removal rate decreased from $4.9 \%$ to less than $1 \%$ when $\mathrm{pH}$ was increased from 4.0 to 9.0, indicating a negative effect of an increase in $\mathrm{pH}$ condition. Similar findings have been reported on selenocyanate adsorption (an organic selenium species) by nZVI [31]. Meng et al. [31] demonstrated that selenocyanate's removal rate increased from $50 \%$ to $97 \%$ when $\mathrm{pH}$ was decreased from 8.5 to 5.5 .

\subsection{Effect of Initial Concentration}

GAC performance in treating water containing different concentrations of SeMet and SeCys at pH 7.0 is presented in Figure 5. For SeMet, $4.9 \mathrm{mg} / \mathrm{L}$ and $46.8 \mathrm{mg} / \mathrm{L}$ of initial concentration were evaluated, while SeCys, 3.8 and $38 \mathrm{mg} / \mathrm{L}$ of initial concentration were examined. Both forms of organoselenium were adsorbed continuously as a function of time until equilibrium was reached. However, SeMet appears to have some desorption after $1 \mathrm{~h}$, which was typical in both concentrations ( 4.9 and $46.8 \mathrm{mg} / \mathrm{L}$ ). The pseudo-second-order kinetic model adequately describes the data depicted in Table 2 . The correlation coefficients $\left(R^{2}\right)$ value was evaluated between 0.999-1.000 (Table 2). As illustrated in Table 2, the rate constant is between 2.50 to 1.80 for SeMet $C_{o}(4.9$ and $46.8 \mathrm{mg} / \mathrm{L})$ and 1.30 to 0.25 for SeCys $C_{0}(3.8$ and $38 \mathrm{mg} / \mathrm{L})$, respectively. The result demonstrates that the rate constant $\left(K_{2}\right)$ decreased with an increase in SeMet and SeCys concentration. When the initial concentration is increased, the solution takes more time to attain equilibrium. The decrease in $K_{2}$, with respect to an increase in the initial concentration, can be attributed to a longer duration that is required for the solution to attain equilibrium; a similar phenomenon has been reported in the literature $[54,55]$. 
(a)

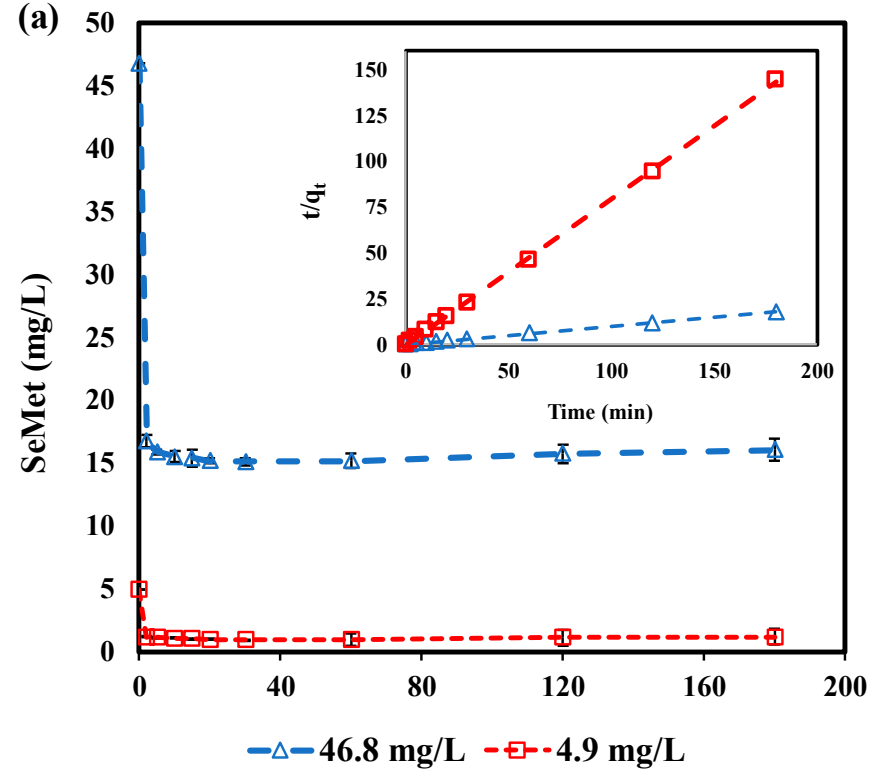

Time (min)

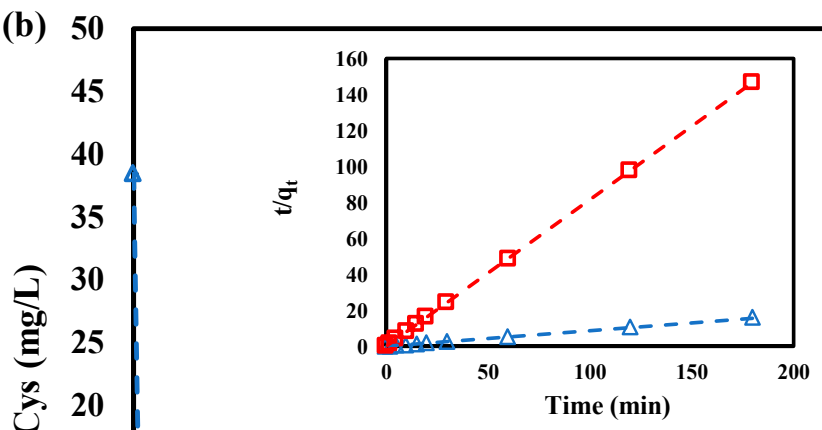

10

5

0

$\begin{array}{lllllllllllll}0 & 20 & 40 & 60 & 80 & 100 & 120 & 140 & 160 & 180 & 200\end{array}$

$-\triangle 38 \mathrm{mg} / \mathrm{L} \quad-\succeq-3.8 \mathrm{mg} / \mathrm{L}$

Time (min)

Figure 5. Effect of initial concentration by GAC: (a) SeMet $\left(C_{o}: 46.8\right.$ and $\left.4.9 \mathrm{mg} / \mathrm{L}\right)$; (b) SeCys $\left(C_{0}: 38\right.$ and $\left.3.8 \mathrm{mg} / \mathrm{L}\right)$; all experiments were conducted at $\mathrm{pH} 7.0,7 \mathrm{~g} / \mathrm{L}$ and $25^{\circ} \mathrm{C}$.

Table 2. Experimental data for adsorbate initial concentration studies with GAC adsorbent, at pH 7.0.

\begin{tabular}{ccccc}
\hline & \multicolumn{3}{c}{ SeMet } & \multicolumn{2}{c}{ SeCys } \\
\hline$C_{o}(\mathrm{mg} / \mathrm{L})$ & 4.9 & 46.8 & 3.8 & 38 \\
$q_{e}\left(\mathrm{mg}^{-1} \mathrm{~g}^{-1}\right)$ & 1.32 & 10.54 & 1.23 & 11.40 \\
$\mathrm{~K}_{2}\left(\mathrm{~g} \cdot \mathrm{mg}^{-1} \cdot \mathrm{min}^{-1}\right)$ & 2.50 & 1.80 & 1.30 & 0.25 \\
$\mathrm{R}^{2}$ & 1.000 & 0.999 & 1.000 & 1.000 \\
\hline
\end{tabular}

Furthermore, the experimental data also show that $q_{e}$ increases with higher $C_{o}$, the increment was significant about eight times higher as the initial concentrations of SeMet and SeCys were varied. It can be deduced that the increase in $C_{o}$ provides the driving force to overcome the mass transfer resistance between the adsorbate and solid phases [56]. It was observed that GAC completely removed $3.8 \mathrm{mg} / \mathrm{L}$ of SeCys in $30 \mathrm{~min}$, while the initial concentration of $38 \mathrm{mg} / \mathrm{L}$ was reduced to $4.2 \mathrm{mg} / \mathrm{L}$ in $3 \mathrm{~h}$. About 30.7 and $3.6 \mathrm{mg} / \mathrm{L}$ of SeMet were adsorbed from the initial concentration of 46.8 and $4.9 \mathrm{mg} / \mathrm{L}$, respectively. An upsurge in adsorption capacity as a result of an increase in adsorbate initial concentration has been reported by Aksu [57] and Al-Ghouti [58].

\subsection{Adsorption Isotherm}

The adsorption data for GAC were evaluated using Langmuir and Freundlich isotherm models. The results of both Langmuir and Freundlich models for SeMet and SeCys adsorption are summarized in Table 3. Freundlich and Langmuir models fitted well with the experimental data $\left(R^{2}>0.950\right)$. Figure 6a shows that the Freundlich model provided a better fit for SeMet adsorption data compared to the Langmuir model. The correlation coefficient $\left(R^{2}>0.996\right)$ was higher for the Freundlich model, suggesting that the adsorption of SeMet might occur in multilayers. The parameter $K_{f}$ of the Freundlich model was calculated to be 1.85 , which is related to the adsorption capacity. As reflected in Table 3, the constant $n$, representing the adsorption intensity, was equal to 1.55 , indicating pseudo linear adsorption [59]. 
Table 3. Adsorption isotherm parameters for organoselenium by GAC.

\begin{tabular}{ccccccc}
\hline & \multicolumn{3}{c}{ Langmuir Model } & \multicolumn{3}{c}{ Freundlich Model } \\
\hline & $\boldsymbol{q}_{\boldsymbol{m}}(\mathbf{m g} / \mathbf{g})$ & $\boldsymbol{K}_{\boldsymbol{c}}(\mathbf{L} / \mathbf{m g})$ & $\mathbf{R}^{\mathbf{2}}$ & $\boldsymbol{K}_{f}$ & $\boldsymbol{n}$ & $\mathbf{R}^{\mathbf{2}}$ \\
\hline SeMet & 18.9 & 0.10 & 0.967 & 1.85 & 1.55 & 0.996 \\
SeCys & 10.0 & 0.32 & 0.999 & 2.52 & 2.14 & 0.950 \\
\hline
\end{tabular}
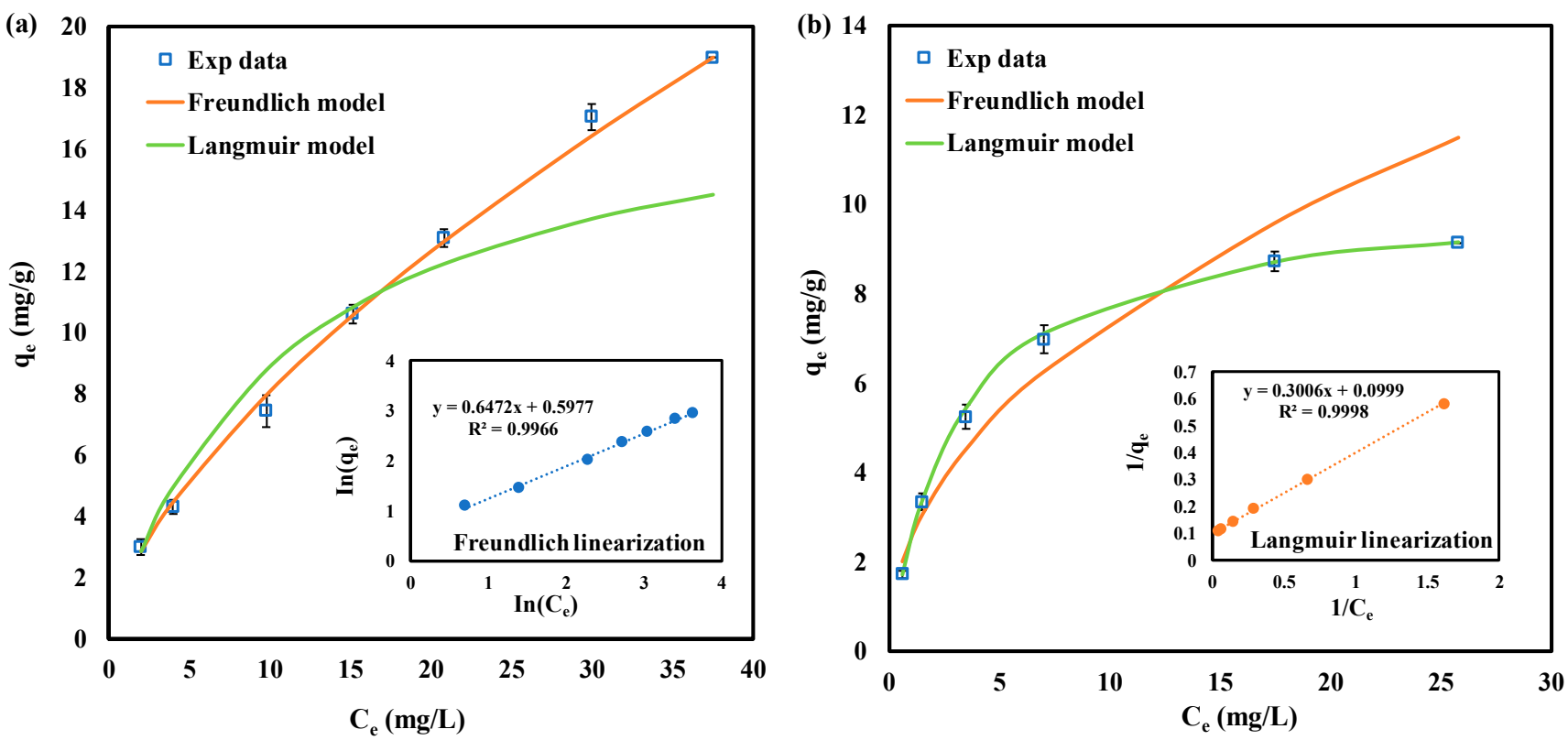

Figure 6. Organic selenium adsorption isotherms by GAC, pH 7.0, at $25^{\circ} \mathrm{C}$. (a) SeMet; (b) SeCys. The solid lines represent model fits; inset shows a linearization fit.

On the other hand, SeCys adsorption by GAC with corresponding Langmuir plots is presented in Figure 6b. Freundlich isotherm was also used to normalize the adsorption data. As stated in Table 3, the isotherm data fitted better with the Langmuir model (higher coefficients of determination $R^{2}=0.990$ ) in contrast to the Freundlich model, suggesting that the adsorption of SeCys is monolayer and it occurred at localized sites $[53,57]$. The maximum uptake capacity for the Langmuir parameter $q_{m}$ is $10 \mathrm{mg} / \mathrm{g}$. The dimensionless constant $R_{L}=0.082$, an indication that SeCys adsorption process can be considered as favorable [41].

\subsection{Adsorption Kinetics}

Figure 7a shows the time-dependent data of SeMet and SeCys adsorption by GAC. As shown in the results (Figure 7a), the equilibrium time for SeMet was 20 min, while SeCys took longer than $50 \mathrm{~min}$ to achieve equilibrium, indicating that the SeCys adsorption process was progressive. The pseudo-second-order (PSO) kinetics model (inset of Figure 6a) was used to investigate the adsorption kinetics, the rate constant $\left(k_{2}\right)$ values and the maximum adsorption capacity $\left(q_{e}\right)$ for SeMet and SeCys, as presented in Table 4 . The correlation coefficients $\left(R^{2}>0.999\right)$ suggest that the PSO model was a good fit for the adsorbents tested. However, when parameter $h$, which accounts for the initial adsorption rate, was calculated, the value shows that SeCys adsorption was faster than SeMet adsorption ( $h$ value of SeMet is about $33 \%$ less than SeCys). 
(a)

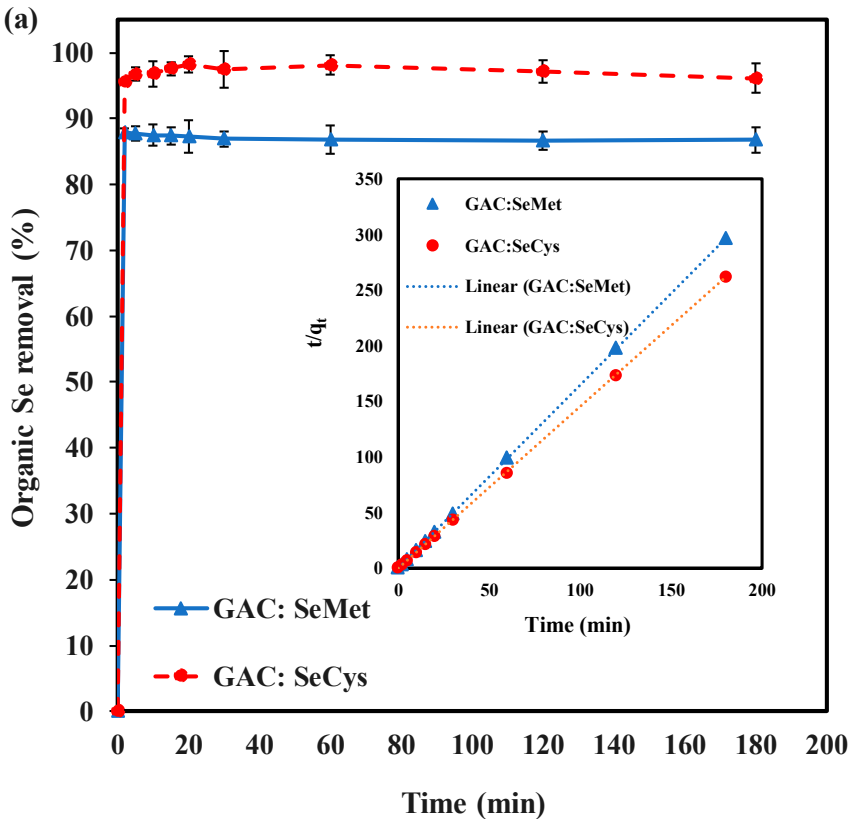

(b)

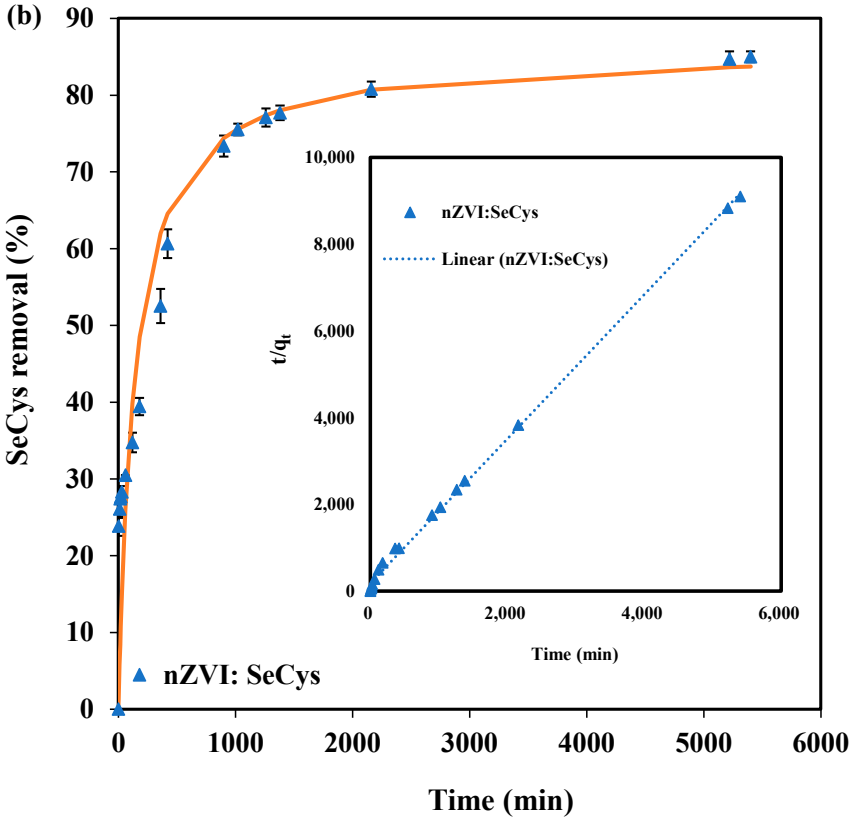

Figure 7. (a) Organic selenium adsorption kinetics using $7 \mathrm{~g} / \mathrm{L}$ of GAC. (b) SeCys adsorption kinetics using $7 \mathrm{~g} / \mathrm{L}$ of $\mathrm{nZVI}$. All experiments were conducted at $\mathrm{pH} 7.0,25^{\circ} \mathrm{C}$ with an initial concentration of $5 \mathrm{mg} / \mathrm{L}$.

Table 4. Kinetic parameters of pseudo-second-order models for SeMet and SeCys adsorption.

\begin{tabular}{ccccc}
\hline \multirow{2}{*}{ Kinetic Parameter } & $\mathbf{p H}$ & SeMet & \multicolumn{2}{c}{ SeCys } \\
\cline { 3 - 5 } & & GAC & nZVI & GAC \\
\hline$q_{e}\left({\left.\mathrm{mg} \cdot \mathrm{g}^{-1}\right)}_{k_{2}\left(\mathrm{~g} \cdot \mathrm{mg}^{-1} \cdot \mathrm{min}^{-1}\right)}^{\mathrm{R}^{2}}\right.$ & 7 & 0.61 & 0.59 & 0.70 \\
$h\left(\mathrm{mg} \cdot \mathrm{g}^{-1} \cdot \mathrm{min}^{-1}\right)$ & & 24 & 0.012 & 28 \\
& & 1.000 & 0.998 & 0.999 \\
\hline
\end{tabular}

The adsorption kinetics of SeCys by nZVI are depicted in Figure $7 \mathrm{~b}$. The experiment was performed for $54 \mathrm{~h}$ to allow enough time for equilibrium. However, equilibrium was not achieved because the adsorption process was very slow (Table 4). The pseudosecond-order kinetics model showed a good fit for SeCys adsorption data $\left(R^{2}>0.998\right)$. Contrary to GAC adsorption, nZVI removal efficiency was found to increase slowly until a final adsorption efficiency of $85 \%$ was achieved. Overall, GAC kinetics was very swift compared to nZVI, which can be explained as an outcome of a more significant adsorption site [43].

\subsection{Binary Adsorption of SeMet and SeCys}

The effect of the coexistence of SeMet and SeCys on wastewaters was investigated using $7 \mathrm{~g} / \mathrm{L}$ of GAC and nZVI. The initial concentration of organic selenium in the mixture was $10 \mathrm{mg} / \mathrm{L}$ (comprising $5 \mathrm{mg} / \mathrm{L}$ of SeMet and SeCys each), and the $\mathrm{pH}$ of the solution was 7.0. The result presented in Figure 8 shows that GAC and nZVI removed $8.9 \mathrm{mg} / \mathrm{L}$ and $1.5 \mathrm{mg} / \mathrm{L}$ of Se from the mixture of SeMet and SeCys, respectively, in $3 \mathrm{~h}$. On an individual basis, GAC removed $4.8 \mathrm{mg} / \mathrm{L}$ of Se from SeCys solution and $4.3 \mathrm{mg} / \mathrm{L}$ of Se from SeMet solution. While nZVI adsorbed $1.9 \mathrm{mg} / \mathrm{L}$ of Se from SeCys and $0.1 \mathrm{mg} / \mathrm{L}$ of Se from SeMet. The result shows that the total Se removed by GAC from the mixture of SeMet and SeCys solution was lower compared to the sum of Se adsorbed in a single solute system. This phenomenon is an indication of competition between different molecules for available adsorption sites on GAC surface $[60,61]$. Conversely, the adsorption of SeMet by nZVI in a single solute system was very weak, indicating that the competing effect for active sites on the surface of nZVI was negligible. The inhibition effect of SeMet on the adsorption of 
SeCys by GAC and nZVI can possibly occur as a result of the interaction between SeCys and SeMet in the binary system. Organic selenium speciation was not determined in this study; hence, the selenium species removed from the mixture was unknown.

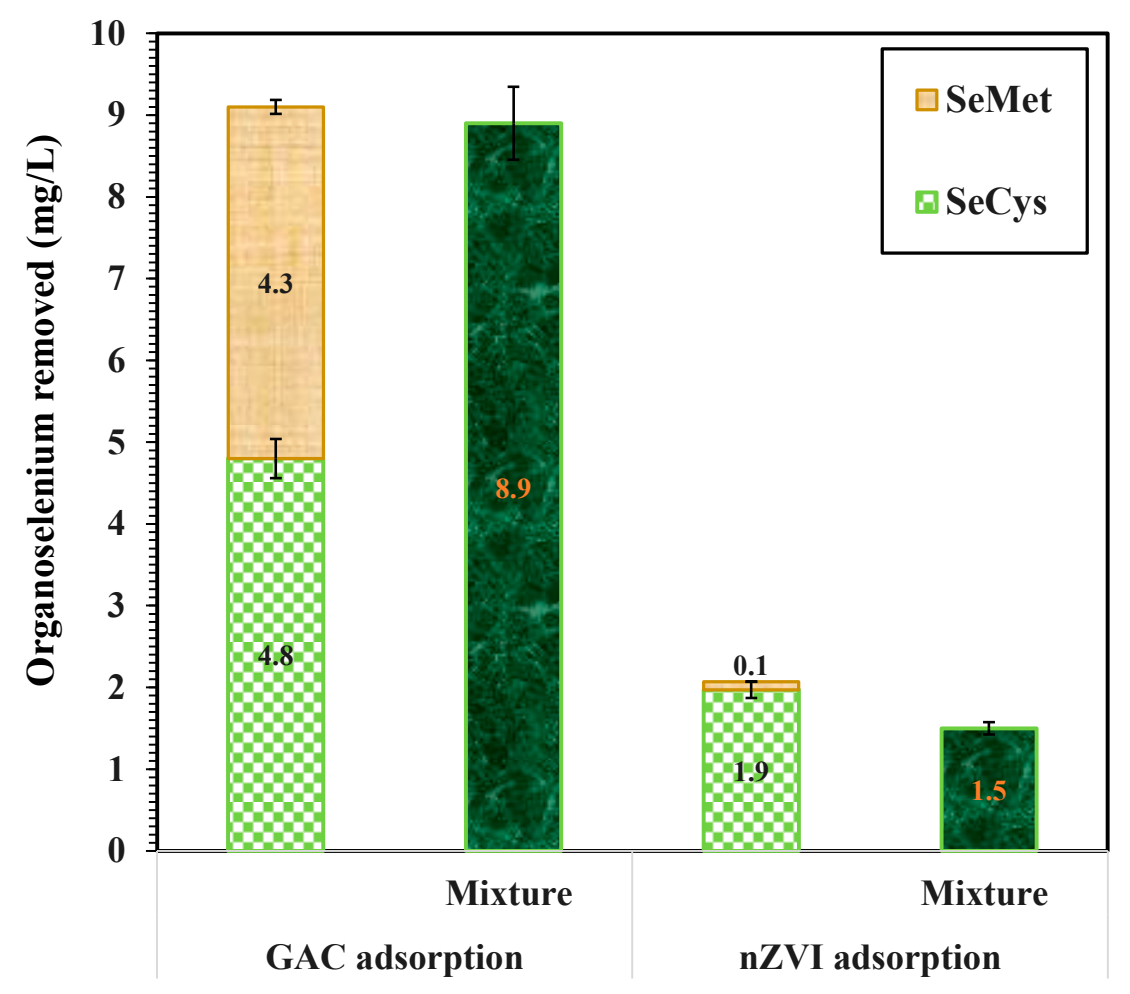

Figure 8. Binary adsorption of SeMet and SeCys by nZVI and GAC, initial concentration of $10 \mathrm{mg} / \mathrm{L}$, $7 \mathrm{~g} / \mathrm{L}$ at $\mathrm{pH} 7.0$ and $25^{\circ} \mathrm{C}$.

\section{Conclusions}

The adsorption of SeMet and SeCys by GAC and nZVI under various conditionsdifferent $\mathrm{pHs}$, adsorbate initial concentration, adsorbent dosage, and binary adsorption were investigated. GAC demonstrated a higher affinity towards the removal of SeMet and SeCys, and was, therefore, considered a better adsorbent candidate. An optimum dose of $7 \mathrm{~g} / \mathrm{L}$ of GAC was found to remove both contaminants effectively. Change in $\mathrm{pH}$ had no significant impact on SeCys removal by GAC; nevertheless, more than $93.99 \%$ removal was achieved at all $\mathrm{pH}$ tested. In the case of nZVI, $\mathrm{pH}$ change substantially influenced the adsorption capacity-at $\mathrm{pH} 4.0$, about $57.8 \%$ of SeCys was removed. An increase in adsorption capacity with a decrease in $\mathrm{pH}$ value was observed for SeMet removal by nZVI. SeCys adsorbed more readily into nZVI compared to SeMet-for all conditions evaluated, SeMet removal by nZVI was less than $5 \%$. The pseudo-second-order kinetics model characterized the adsorption of organoselenium by both adsorbents. The fastest adsorption kinetics was observed with GAC under neutral $\mathrm{pH}$, where an instantaneous removal of organic selenium was observed. Binary adsorption of SeCys and SeMet indicates an inhibitory effect on SeCys removal by SeMet. The adsorption data fitted well with both Langmuir and Freundlich isotherm models.

Author Contributions: Conceptualization, S.O.O., G.A. and D.P.; methodology, S.O.O.; experimental design, S.O.O. and L.Y.; formal analysis, S.O.O. and J.A.D.; investigation, S.O.O.; resources, G.A; writing—original draft preparation, S.O.O.; writing—review and editing, G.A, L.Y., D.P. and J.A.D.; supervision, G.A; project administration, J.A.D.; funding acquisition, G.A. All authors have read and agreed to the published version of the manuscript.

Funding: Natural Sciences and Engineering Research Council of Canada (NSERC). 
Data Availability Statement: The data presented in this study are available on request from the corresponding author.

Acknowledgments: The authors gratefully acknowledge the funding support provided by National Sciences and Engineering Research Council of Canada (NSERC) through an Engage grant.

Conflicts of Interest: The authors declare no conflict of interest.

\section{References}

1. Maseko, T.; Callahan, D.L.; Dunshea, F.R.; Doronila, A.; Kolev, S.D.; Ng, K. Chemical characterisation and speciation of organic selenium in cultivated selenium-enriched Agaricus bisporus. Food Chem. 2013, 141, 3681-3687. [CrossRef] [PubMed]

2. Dumont, E.; Vanhaecke, F.; Cornelis, R. Selenium speciation from food source to metabolites: A critical review. Anal. Bioanal. Chem. 2006, 385, 1304-1323. [CrossRef] [PubMed]

3. Amoako, P.O.; Uden, P.C.; Tyson, J.F. Speciation of selenium dietary supplements; formation of S-(methylseleno) cysteine and other selenium compounds. Anal. Chim. Acta 2009, 652, 315-323. [CrossRef] [PubMed]

4. Albert, M.; Demesmay, C.; Rocca, J. Analysis of organic and non-organic arsenious or selenious compounds by capillary electrophoresis. Fresenius' J. Anal. Chem. 1995, 351, 426-432. [CrossRef]

5. LeBlanc, K.L.; Wallschläger, D. Production and release of selenomethionine and related organic selenium species by microorganisms in natural and industrial waters. Environ. Sci. Technol. 2016, 50, 6164-6171. [CrossRef] [PubMed]

6. Lemly, A.D. Environmental implications of excessive selenium: A review. Biomed. Environ. Sci. 1997, 10, 415-435.

7. Fan, A.M.; Book, S.A.; Neutra, R.R.; Epstein, D.M. Selenium and human health implications in California's San Joaquin Valley. J. Toxicol. Environ. Health Part A Curr. Issues 1988, 23, 539-559. [CrossRef]

8. Delos, C. Draft Aquatic Life Water Quality Criteria for Selenium; US Environmental Protection Agency: Washington, DC, USA, 2004

9. CH2M HILL. Review of available technologies for the removal of selenium from water. In Final Report, Prepared for North American Metals Council (NAMC); CH2M HILL: Charlotte, NC, USA; Bellevue, WA, USA, 2010.

10. Khamkhash, A.; Srivastava, V.; Ghosh, T.; Akdogan, G.; Ganguli, R.; Aggarwal, S. Mining-related selenium contamination in Alaska, and the state of current knowledge. Minerals 2017, 7, 46. [CrossRef]

11. Zhang, Y.; Amrhein, C.; Frankenberger, W.T., Jr. Effect of arsenate and molybdate on removal of selenate from an aqueous solution by zero-valent iron. Sci. Total Environ. 2005, 350, 1-11. [CrossRef]

12. Mondal, K.; Jegadeesan, G.; Lalvani, S.B. Removal of selenate by Fe and NiFe nanosized particles. Ind. Eng. Chem. Res. 2004, 43, 4922-4934. [CrossRef]

13. Montgomery, J.M.; Engineers, C. Water Treatment Principles and Design; Wiley: New York, NY, USA, 1985.

14. Mavrov, V.; Stamenov, S.; Todorova, E.; Chmiel, H.; Erwe, T. New hybrid electrocoagulation membrane process for removing selenium from industrial wastewater. Desalination 2006, 201, 290-296. [CrossRef]

15. Balistrieri, L.S.; Chao, T. Selenium Adsorption by Goethite. Soil Sci. Soc. Am. J. 1987, 51, 1145-1151. [CrossRef]

16. Balistrieri, L.S.; Chao, T. Adsorption of selenium by amorphous iron oxyhydroxide and manganese dioxide. Geochim. Cosmochim. Acta 1990, 54, 739-751. [CrossRef]

17. Zhang, Y.; Frankenberger, W.T. Factors affecting removal of selenate in agricultural drainage water utilizing rice straw. Sci. Total Environ. 2003, 305, 207-216. [CrossRef]

18. Peak, D. Adsorption mechanisms of selenium oxyanions at the aluminum oxide/water interface. J. Colloid Interface Sci. 2006, 303, 337-345. [CrossRef]

19. El-Shafey, E. Sorption of Cd (II) and Se (IV) from aqueous solution using modified rice husk. J. Hazard. Mater. 2007, 147, 546-555. [CrossRef]

20. Zhang, N.; Gang, D.; Lin, L.-S. Adsorptive removal of parts per million level Selenate using iron-coated GAC Adsorbents. J. Environ. Eng. 2010, 136, 1089-1095. [CrossRef]

21. Zhang, N.; Lin, L.-S.; Gang, D. Adsorptive selenite removal from water using iron-coated GAC adsorbents. Water Res. 2008, 42, 3809-3816. [CrossRef]

22. Hu, C.; Chen, Q.; Chen, G.; Liu, H.; Qu, J. Removal of Se (IV) and Se (VI) from drinking water by coagulation. Sep. Purif. Technol. 2015, 142, 65-70. [CrossRef]

23. Tan, T.; Beydoun, D.; Amal, R. Effects of organic hole scavengers on the photocatalytic reduction of selenium anions. J. Photochem. Photobiol. A Chem. 2003, 159, 273-280. [CrossRef]

24. Nguyen, V.N.H.; Beydoun, D.; Amal, R. Photocatalytic reduction of selenite and selenate using $\mathrm{TiO}_{2}$ photocatalyst. J. Photochem. Photobiol. A Chem. 2005, 171, 113-120. [CrossRef]

25. Zhang, Y.; Moore, J.N. Environmental conditions controlling selenium volatilization from a wetland system. Environ. Sci. Technol. 1997, 31, 511-517. [CrossRef]

26. Amweg, E.; Stuart, D.; Weston, D. Comparative bioavailability of selenium to aquatic organisms after biological treatment of agricultural drainage water. Aquat. Toxicol. 2003, 63, 13-25. [CrossRef]

27. Zhang, Y.; Okeke, B.C.; Frankenberger, W.T., Jr. Bacterial reduction of selenate to elemental selenium utilizing molasses as a carbon source. Bioresour. Technol. 2008, 99, 1267-1273. [CrossRef] [PubMed] 
28. Presser, T.S.; Ohlendorf, H.M. Biogeochemical cycling of selenium in the San Joaquin Valley, California, USA. Environ. Manag. 1987, 11, 805-821. [CrossRef]

29. Ohlendorf, H.M. Bioaccumulation and Effects of Selenium in Wildlife. Selenium Agric. Environ. 1989, 23, $133-177$.

30. Manceau, A.; Gallup, D.L. Removal of Selenocyanate in Water by Precipitation: Characterization of Copper-Selenium Precipitate by X-ray Diffraction, Infrared, and X-ray Absorption Spectroscopy. Environ. Sci. Technol. 1997, 31, 968-976. [CrossRef]

31. Meng, X.; Bang, S.; Korfiatis, G.P. Removal of selenocyanate from water using elemental iron. Water Res. 2002, 36, 38673873. [CrossRef]

32. Latva, S.; Peräniemi, S.; Ahlgrén, M. Study of metal-loaded activated charcoals for the separation and determination of selenium species by energy dispersive X-ray fluorescence analysis. Anal. Chim. Acta 2003, 478, 229-235. [CrossRef]

33. Okonji, S.O.; Dominic, J.A.; Pernitsky, D.; Achari, G. Removal and recovery of selenium species from wastewater: Adsorption kinetics and co-precipitation mechanisms. J. Water Process Eng. 2020, 38, 101666. [CrossRef]

34. Yoon, I.-H.; Kim, K.-W.; Bang, S.; Kim, M.G. Reduction and adsorption mechanisms of selenate by zero-valent iron and related iron corrosion. Appl. Catal. B Environ. 2011, 104, 185-192. [CrossRef]

35. Wasewar, K.L.; Prasad, B.; Gulipalli, S. Removal of selenium by adsorption onto granular activated carbon (GAC) and powdered activated carbon (PAC). CLEAN-Soil Air Water 2009, 37, 872-883. [CrossRef]

36. Das, S.; Lindsay, M.B.; Essilfie-Dughan, J.; Hendry, M.J. Dissolved selenium (VI) removal by zero-valent iron under oxic conditions: Influence of sulfate and nitrate. ACS Omega 2017, 24, 1513-1522. [CrossRef] [PubMed]

37. Zhang, Y.; Wang, J.; Amrhein, C.; Frankenberger, W.T. Removal of selenate from water by zerovalent iron. J. Environ. Qual. 2005, 34, 487-495. [CrossRef] [PubMed]

38. Liang, L.; Jiang, X.; Yang, W.; Huang, Y.; Guan, X.; Li, L. Kinetics of selenite reduction by zero-valent iron. Desalination Water Treat. 2015, 53, 2540-2548. [CrossRef]

39. Zelmanov, G.; Semiat, R. Selenium removal from water and its recovery using iron (Fe3+) oxide/hydroxide-based nanoparticles sol (NanoFe) as an adsorbent. Sep. Purif. Technol. 2013, 103, 167-172. [CrossRef]

40. Langmuir, I. The constitution and fundamental properties of solids and liquids. Part I. Solids. J. Am. Chem. Soc. 1916, 38, 2221-2295. [CrossRef]

41. Zeng, G.; Liu, Y.; Tang, L.; Yang, G.; Pang, Y.; Zhang, Y.; Zhou, Y.; Li, Z.; Li, M.; Lai, M. Enhancement of Cd (II) adsorption by polyacrylic acid modified magnetic mesoporous carbon. Chem. Eng. J. 2015, 259, 153-160. [CrossRef]

42. Bansal, R.; Goyal, M. Activated carbon adsorption and environment: Adsorptive removal of organic from water. In Activated Carbon Adsorption; Taylor \& Francis: Boca Raton, FL, USA, 2005; pp. 297-372.

43. Yang, Y.; Yu, L.; Iranmanesh, S.; Keir, I.; Achari, G. Laboratory and Field Investigation of Sulfolane Removal from Water Using Activated Carbon. J. Environ. Eng. 2020, 146, 04020022. [CrossRef]

44. Ahnert, F.; Arafat, H.A.; Pinto, N.G. A study of the influence of hydrophobicity of activated carbon on the adsorption equilibrium of aromatics in non-aqueous media. Adsorption 2003, 9, 311-319. [CrossRef]

45. López-Velandia, C.; Moreno-Barbosa, J.J.; Sierra-Ramirez, R.; Giraldo, L.; Moreno-Piraján, J.C. Adsorption of volatile carboxylic acids on activated carbon synthesized from watermelon shells. Adsorpt. Sci. Technol. 2014, 32, 227-242. [CrossRef]

46. Mundlapati, V.R.; Sahoo, D.K.; Ghosh, S.; Purame, U.K.; Pandey, S.; Acharya, R.; Pal, N.; Tiwari, P.; Biswal, H.S. Spectroscopic evidence for strong hydrogen bonds with selenomethionine in proteins. J. Phys. Chem. Lett. 2017, 8, 794-800. [CrossRef] [PubMed]

47. Adusei-Gyamfi, J.; Acha, V. Carriers for nano zerovalent iron (nZVI): Synthesis, application and efficiency. RSC Adv. 2016, 6, 91025-91044. [CrossRef]

48. Wang, Q.; Kanel, S.R.; Park, H.; Ryu, A.; Choi, H. Controllable synthesis, characterization, and magnetic properties of nanoscale zerovalent iron with specific high Brunauer-Emmett-Teller surface area. J. Nanoparticle Res. 2009, 113, 749-755. [CrossRef]

49. Oguzie, E.; Li, Y.; Wang, F. Corrosion inhibition and adsorption behavior of methionine on mild steel in sulfuric acid and synergistic effect of iodide ion. J. Colloid Interface Sci. 2007, 310, 90-98. [CrossRef] [PubMed]

50. Thomsen, L.; Wharmby, M.; Riley, D.; Held, G.; Gladys, M. The adsorption and stability of sulfur containing amino acids on Cu \{5 3 1\}. Surf. Sci. 2009, 603, 1253-1261. [CrossRef]

51. Mishra, B.; Priyadarsini, K.; Mohan, H. One-Electron Oxidation of Selenomethionine in Aqueous Solutions. Barc Newslett. 2005, 261, 115.

52. Bettelheim, F.A.; Brown, W.H.; Campbell, M.K.; Farrell, S.O.; Torres, O. Introduction to General, Organic and Biochemistry; Nelson Education: Toronto, ON, Canada, 2012.

53. Cermakova, L.; Kopecka, I.; Pivokonsky, M.; Pivokonska, L.; Janda, V. Removal of cyanobacterial amino acids in water treatment by activated carbon adsorption. Sep. Purif. Technol. 2017, 173, 330-338. [CrossRef]

54. Gupta, S.S.; Bhattacharyya, K.G. Kinetics of adsorption of metal ions on inorganic materials: A review. Adv. Colloid Interface Sci. 2011, 162, 39-58. [CrossRef]

55. Allen, S.J.; Gan, Q.; Matthews, R.; Johnson, P.A. Kinetic modeling of the adsorption of basic dyes by kudzu. J. Colloid Interface Sci. 2005, 286, 101-109. [CrossRef]

56. Wang, W.; Wang, J.; Guo, Y.; Zhu, C.; Pan, F.; Wu, R.; Wang, C. Removal of multiple nitrosamines from aqueous solution by nanoscale zero-valent iron supported on granular activated carbon: Influencing factors and reaction mechanism. Sci. Total Environ. 2018, 639, 934-943. [CrossRef] [PubMed] 
57. Aksu, Z.; Dönmez, G. A comparative study on the biosorption characteristics of some yeasts for Remazol Blue reactive dye. Chemosphere 2003, 50, 1075-1083. [CrossRef]

58. Al-Ghouti, M.A.; Khraisheh, M.A.; Ahmad, M.N.; Allen, S. Adsorption behaviour of methylene blue onto Jordanian diatomite: A kinetic study. J. Hazard. Mater. 2009, 165, 589-598. [CrossRef] [PubMed]

59. Tseng, R.-L.; Wu, F.-C. Inferring the favorable adsorption level and the concurrent multi-stage process with the Freundlich constant. J. Hazard. Mater. 2008, 155, 277-287. [CrossRef]

60. Jain, J.S.; Snoeyink, V.L. Adsorption from bisolute systems on active carbon. J. Water Pollut. Control Fed. 1973, 45, $2463-2479$.

61. Noroozi, B.; Sorial, G.; Bahrami, H.; Arami, M. Adsorption of binary mixtures of cationic dyes. Dyes Pigment. 2008, 76, 784-791. [CrossRef] 